\title{
In vivo Effects of the Synalbumin Insulin Antagonist*
}

\author{
L. KaMMerer** and J. VALLANCE-OWEN \\ Department of Medicine, The Queen's University of Belfast, Northern Ireland \\ Received: March 25, 1968
}

\begin{abstract}
Summary. Albumin prepared from serum of diabetic patients inhibits the effect of insulin on rat diaphragm muscle but not on their epididymal fat pads when injected intravenously to make a foreign protein concentration of $3.8 \mathrm{~g} / 100 \mathrm{ml}$ in the plasma of the rat. At this concentration, albumin from normal subjects had no insulin inhibitory effect on either tissue. - These observations confirm, under in vivo conditions, that diabetic albumin is more antagonistic to insulin than albumin prepared from normal subjects.
\end{abstract} bumine

Effets in vivo de l'antagoniste de l'insuline, la synal-

Résumé. L'albumine préparée à partir du sérum de sujets diabétiques inhibe l'effet de l'insuline sur le muscle du diaphragme du rat mais n'a pas d'effet sur le tissu adipeux épididymaire, quand elle est injectée par voie intraveineuse pour produire une concentration de protéine étrangère de $3.8 \mathrm{~g} / 100 \mathrm{ml}$ dans le plasma du rat. A cette concentration, l'albumine de sujets normaux n'a pas d'effet inhibiteur sur l'insuline pour les deux tissus. - Ces observations confirment, dans les conditions in vivo, que l'albumine diabétique est plus antagoniste de l'insuline que l'albumine obtenue à partir de sujets normaux.

In vivo Effekte der Synalbumin Insulin Antagonisten

Zusammenfassung. Aus diabetischen Seren präpariertes Albumin hemmt die Insulinwirkung am Zwerchfellmuskel, aber n' cht am epididymalen. Fettgewebe der Ratte, wenn bei i. v. Zufuhr eine Konzentration des Fremdeiweißes von $3.8 \mathrm{~g} \%$ im Plasma der Ratten erreicht wird. Dagegen hemmt in der gleichen Konzentration verabreichtes Albumin, das aus Normalseren gewonnen wurde, den Insulineffekt an keinem der beiden Gewebe. Diese Beobachtungen bestätigen, daß auch unter in vivo Bedingungen diabetisches Albumin die Insulinwirkung stärker hemmt als das Albumin von Normalpersonen.

Key-words: Antagonism, fat, glycogen, insulin, in vivo, muscle, synalbumin.
Human plasma albumin inhibits the effect of insulin on the rat diaphragm muscle in vitro $[8,13,16,18]$, and several workers have confirmed the original observations of VALLANCE-OwEN et al. [18], that there is more antagonism to insulin with albumin prepared from the plasma of diabetic patients $[1,2,6,11,12$, 16]. In each case the antagonistic effect is not due to the albumin itself but to some substance associated with it - hence the term, synalbumin insulin antagonist [17].

However, when human albumin (Cohn fraction V) previously shown to be antagonistic to insulin in vitro, was infused over three hours into the femoral vein of lightly anaesthetised non-fasting rats, no antagonism to insulin or diabetogenic effect could be demonstrated [4]. Initially the albumin was infused at a rate of $180 \mathrm{mg} /$ hour for three hours achieving a foreign protein concentration of $3.4 \mathrm{~g} / 100 \mathrm{ml}$ and later the rate was increased to $450 \mathrm{mg} /$ hour for three hours being equivalent to $5.5 \mathrm{~g} / 100 \mathrm{ml}$ foreign protein. In these studies there was no effect on the plasma insulin concentration or on the establishment of steady blood sugar levels and diaphragms from the animals were not less insulin sensitive in vitro.

Nevertheless Jervell [9], and JeRvell and VALLANCE-OWEN [10], using the intraperitoneal technique of RAFAGLSON [14, 15], showed that this synal-

* Supported by grants from the British Diabetic Association and Queen's University, Belfast.

** Present address: IIIrd Department of Medicine, The University of Budapest, Hungary. bumin antagonist opposed insulin action on muscle in vivo although not modifying the effect of insulin on fat tissue.

In vitro assays and intraperitoneal injections of albumin can be criticised because of the unphysiological contact of the protein with the diaphragm and clearly intravenous administration of the albumin would be preferable. Accordingly we have investigated the effect of the synalbumin insulin antagonist on glycogen formation in muscle and fat tissue of rats when this material is injected intravenously.

\section{Material and Methods}

Albumin was prepared from the fresh serum of fasting healthy volunteers and of fasting diabetic patients by the trichloroacetic acid/ethanol procedure of Derro $[5,18]$, and by the method of Fernandez et. al. [7] which does not involve trichloroacetic acid or dialysis. Ordinarily, single preparations of albumin were used, although in some experiments two albumin samples were pooled, in order to provide sufficient protein.

Male Wistar rats weighing $90-130 \mathrm{~g}$ were investigated, but on any one experimental day animals of the same weight were used. The rats, which were fed but unanaesthetised were injected intravenously, using the tail vein, with Gey \& Gey buffer $(2.5 \mathrm{ml}$ per $100 \mathrm{~g}$ bodyweight) containing $1000 \mu \mathrm{U}$ insulin and $4 \mu \mathrm{C}{ }^{14} \mathrm{C}$-labelled glucose alone or together with either 
albumin from normal subjects or from diabetic patients in a concentration of $250 \mathrm{mg}$ per $100 \mathrm{~g}$ rat. This achieves, at the time of injection, a human albumin concentration of $3.8 \mathrm{~g} / 100 \mathrm{ml}$ in the plasma of the rat. The concentration in the total blood volume would be $2.8 \mathrm{~g} / 100 \mathrm{ml}$.

Nine animals were used in any one experiment, three being injected with insulin and ${ }^{14} \mathrm{C}$-labelled glucose alone, three with insulin, ${ }^{14} \mathrm{C}$-glucose and normal albumin and three with insulin, ${ }^{14} \mathrm{C}$-glucose and diabetic albumin. After $30 \mathrm{~min}$ the rats were killed and the radioactivity was determined in glycogen isolated from each half of the diaphragm muscle and each epididymal fat pad after the method of RAFAELSEN et al. [15]. Both the hemidiaphragms and fat pads were immediately weighed on a torsion balance. The epididymal fat tissue was extracted with a mixture of two parts of chloroform and one part of methanol for $24 \mathrm{~h}$, after which the tissue was dried. The hemidiaphragms and fat pads were placed in $0.5 \mathrm{ml} 30 \%$ potassium hydroxide and hydrolysed by boiling for 30 min in a water bath. Following this the glycogen was precipitated by the addition of $0.1 \mathrm{ml} 2 \%$ Sodium sulphate and $1.5 \mathrm{ml}$ absolute ethanol for each $0.5 \mathrm{ml}$ hydrolysate, and allowed to stand at room temperature for $24 \mathrm{~h}$. The samples were centrifuged and the supernatant discarded while the precipitate was washed once with $2 \mathrm{ml} 70 \%$ ethanol and subjected to a second centrifugation. After drying, the precipitates were dissolved in $1.0 \mathrm{ml} 0.1 \mathrm{~N} \mathrm{H}_{2} \mathrm{SO}_{4}$ and boiled for three hours in a water bath. Following this $0.1 \mathrm{ml}$ from the diaphragm preparation and $0.2 \mathrm{ml}$ from the fat pad preparation, was pipetted into $5 \mathrm{ml}$ scintillation fluid and the counts/minute were determined by a Packard Tricarb Counter. The results were calculated as counts per minute per $\mathrm{mg}$ wet tissue and expressed as a percentage of the incorporation with insulin and glucose alone, in order to facilitate comparison between separate experiments.

All albumin samples were tested at a concentration of $1.25 \%$ for insulin antagonism in vitro $[18,19]$ those from diabetic patients being antagonistic, those from normal subjects non-antagonistic.

\section{Results and Discussion}

The results of intravenous injection of albumin from normal subjects and diabetic patients into fed unanaesthetised rats are shown in Fig. 1. There is a clear antagonistic effect of albumin from diabetic patients on the rat diaphragm muscle with no such action on the fat pads.

At this concentration $(3.8 \mathrm{~g} / 100 \mathrm{ml})$ and under these conditions, albumin from normal subjects has no antagonistic effect on the muscle tissue, however in one experiment the concentration was doubled when antagonism was achieved.

It is noteworthy that diabetic albumin antagonises insulin action on muscle to the same extent whether it is prepared by the trichloroethanol method of DEBRo or by the FERNANDEZ method which involves no dialysis.

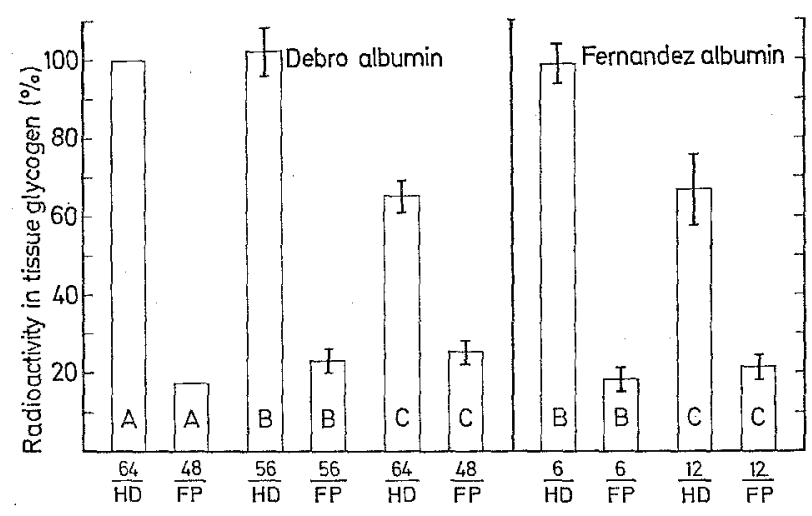

Fig. 1. Insulin antagonistic effect of albumin on rat diaphragm and adipose tissue in vivo: In each experiment glycogen formation with albumin, ${ }^{14} \mathrm{C}$ glucose and insulin was expressed as a percentage of the formation with insulin and glucose alone (Cols. 1\&2), because of the unavoidable variation in radioactivity from day to day

Key A - Insulin + 14 C Glucose

B - Insulin + 14 C Glucose + normal albumin

$\mathrm{C}$ - Insulin + 14 C Glucose + diabetic albumin

$\frac{64}{\mathrm{HD}}-64$ Hemidiaphragms

$\frac{48}{\text { FP }}-48$ Fat pads

These results indicate, in vivo as in vitro, that albumin from diabetic patients is more antagonistic to insulin than albumin prepared from normal subjects.

Much in vitro work has also shown that the synalbumin insulin antagonist, although antagonistic on the rat diaphragm, does not reduce the effectiveness of insulin on the fat pad $[2,13]$. We have also confirmed these observations under in vivo conditions.

\section{References}

1. Atr, H., H. ChapiIN, and L. RigCANT: Partial purification of an insulin inhibitor from human albumin fractions. J. clin. Endocr. 26, 340-351 (1966).

2. - , and L. RECANT: Effect of the insulin-inhibitory albumin fraction from normal and diabetic subjects on adipose tissue. Metabolism 13, 609-619 (1964).

3. - - Studies on the insulin-inhibitory effect of human albumin. J. clin. Invest. 44, 870-822 (1965).

4. Davioson, M.B., and C.J. Goodner: Failure of synalbumin to exhibit insulin antagonism in vivo. Diabetes 16, 386-394 (1967).

5. Debro, J.R., H. TARver, and A. Korner. The determination of serum albumin and globulin by a new method. J. Lab. clin. Med. 50, 728-732 (1957).

6. EHRLICH, R.M., and J.M. MARTIN : Presence of synalbumin antagonist in siblings of diabetic children. Diabetes 15, 400-405 (1966).

7. Fernaviez, A., C. SobmL, and H. GoldenderG: An improved method for determination of serum albumin and globulin. Clin. Chem. 12, 194-198 (1966).

8. JERVELI, J.: The antagonistic effect of human plasma albumin on the insulin stimulated glucose uptake of the isolated rat diaphragm. Acta physiol. scand. 65, $33-44$ (1965). 
9. - Insulin antagonistic effect of human plasma albumin on protein synthesis in vitro and on glycogen synthesis in vivo in the rat diaphragm muscle. Acta phy siol. scand. 66, 300-306 (1966).

10. - , and J. VALLANCE-OWEN : In vivo effect of the synalbumin and B-chain albumin insulin antagonist. Lancet 1967 II, 21-22.

11. Kammerer, L., M. Brítan, L. Nemesánsziky, L. JAKAB, and S. VIRÁG: A plasma synalbumin antagonist. Lancet $1966 \mathrm{II}, 1366-1367$.

12. Kumblaring, W.J., P.M. Congaluy, and A.D. MeERITr : Insulin antagonism in families with juvenile diabetes mellitus. Third International Congress of $\mathrm{Hu}$ man Genetics, Chicago, Sept. 5-10 (1966).

13. Lowy, C., G. Blatchard, and D. PHear: Antagonism of insulin by albumin. Lancet $1961 \mathrm{I}, 802-804$.

14. RAFAELSEN, O.J.: Glycogen content of rat diaphragm after intraperitoneal injection of insulin and other hormones. Acta physiol. scand. 61, 314-322 (1964).
15. - V. LAURIs, and A. E. Renold : Localized intraperitoneal action of insulin on rat diaphragm and epididy. mal adipose tissue in vivo. Diabetes 14, 19-26 (1965).

16. Shermax, L.: The Vallance-Owen ('synalbumin') insulin antagonist. Reproducability and reliability of results in non-diabetic and diabetic humans. Diabetes 15, 149-159 (1966).

17. Vallande-OWeN, J.: Synalbumin insulin antagonism. Diabetes 13, 241-246 (1964).

18. - E. Dennes, and P.N. CAMpbeis: Insulin antagonism in plasma of diabetic patients and normal sub. jects. Lancet $1958 \mathrm{I}, 336-338$.

19. - and B. HuRLOCK: Estimation of plasma insulin by the rat diaphragm method. Lancet 1954 I, 68-70.

Prof. Dr. J. VALTANCE-OWEN Department of Medicine Queen's University of Belfast Grosvenor Road, Belfast 12 Northern Ireland 